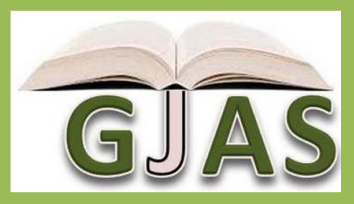

\title{
Biometry of Male Genitalia and Internal Organ Characteristics of Indigenous Genotypes of Domestic Fowl in the Southern Guinea Savanna Region of Nigeria
}

\section{Ahemen T, Ochefu J and Mtem S}

\author{
Department of Animal Breeding and Physiology, University of Agriculture, Makurdi.
}

ARTICLE INFO

Article No.: 031716065

DOI: 10.15580/GJAS.2016.4.031716065

Submitted: 17/03/2016

Accepted: 22/03/2016

Published: 25/04/2016

${ }^{*}$ Corresponding Author

Ahemen $T$

E-mail: drtahemen @gmail .com

Phone: $+234(0) 8132046850$

Keywords:

Genotypes, naked neck, frizzle

feather, normal feather, Male

genitalia

\section{ABSTRACT}

A total of Thirty Nigerian indigenous genotypes of the domestic fowl, aged between 22-25 weeks were used to evaluate the biometry of male genitalia and internalorgan characteristics. The result showed significant $(p<0.05)$ effect of genotype, on right epididymis weight with naked neck having a higher mean value of $0.17 \pm 0.60 \mathrm{~g}$ and normal feather with least value of $0.14 \pm 0.03 \mathrm{~g}$. The paired vas deferens weight was significantly higher for frizzle feather $(0.90 \pm 0.12 \mathrm{~g}$. lower in normal feather $(0.67 \pm 0.24 \mathrm{~g})$ and naked neck $(0.64 \pm 0.15)$. The left testis length was significantly higher $(3.83 \pm 1.13 \mathrm{~cm})$ in normal feather and naked neck $(2.83 \pm 0.20 \mathrm{~cm})$ and least in frizzle feather $(1.93 \pm 0.38 \mathrm{~cm})$.The left testis length follows the same trend. Significant effect of genotype was not observed on paired testes weight, Testis volume, epididymal lengths and vas deferens lengths. No significant $(P>0.05)$ effect of Genotype was observedon absolute weights of heart, lungs and kidney; but significant effect $(P<0.05)$ was found on relative weights of spleen, lungs and liver. The study provide baseline data for Nigeria indigenous genotypes of domestic fowl in the southern guinea savanna region which may be useful for future studies and breeding programmes aimed at genetic improvement of the reproductive performance of local chickens in Nigeria. 


\section{INTRODUCTION}

Indigenous chicken constitutes $80 \%$ of the 120 million poultry type raised in the rural areas in Nigeria (Rim, 1992). In general, an average indigenous fowl in the tropics weighs $0.9-1.8 \mathrm{~kg}$ and possesses a well fleshed, compact body with somewhat light covering of wiry feathers that are free from down. They are tolerant and resistant to certain tropical diseases. Horst (1988) reported that the genetic resource base of the indigenous chicken in the tropics is rich and should form the basis for genetic improvement and diversification to produce a breed adapted to the tropics.

Three genotypes can be identified in the indigenous fowl in Nigeria (Okeet al. 2007); the normal feather, naked neck and upturned feathers (that is, frizzled). Their feather colours vary, ranging from black to darker or lighter shade of brown intermingled with red or gold. Black is very common while white is unusual. Genetic improvement of farm animals may rely on the use of limited number of males either for natural mating or in artificial insemination programmes. It is therefore necessary to evaluate the reproductive performance of tropical birds to help in selecting those males that could be used in breeding programmes and for sustainable meat and egg production in Nigeria (Oke and Ihemeson, 2010).Siddiquiet al.(2005) stated that reproductive performance depends upon the normal structure and function of genital organs of an animal. The knowledge of basic morphometric characteristics of reproductive organs is of great value in breeding soundness evaluation and potential fertility in breeding males (Ibrahim et al., 2012). Egbunikeet al. (1976) opined that morphometric analysis on the testes of any specie or breed is necessary in assessing and estimating qualitative changes in testicular components and spermatogenic functions arising from factors such as age, season, temperature, and diseases.

The reproductive traits of a male chicken are intra-abdominal and located on either side of the midline attached to the roof of the coelom. The organs consist of the paired testes, the epididymis, the ductus deferensand the mating organ(Lake et al., 1985). The testes are the biological industry in male species involved in sperm production and hormonal secretion. During passage of spermatozoa through the epididymis, the sperm cells produced by the testis is matured and stored for use during mating(Hafez and Hafez, 2000).

Biometry of male genitalia and internal organ characteristics of domestic fowl has been reported elsewhere. Butlittle is known about the biometry of the male genitalia and organ characteristics of Nigeria indigenous genotypes of domestic fowl. Hence, the need for a study to provide baseline data on weights and dimensions of different segmentsof male genitalia that could be used for the improvement of the reproductive capacity within the genotypes. This study was carried out to evaluate the biometry of the male genitalia and organ characteristics of indigenous genotypes of domestic fowl in the southern guinea savanna region of Nigeria.

\section{MATERIALS AND METHODS}

\section{Experimental site}

The experiment was carried out at the Veterinary physiology Laboratory, University of Agriculture Makurdi. Makurdi is located at Latitude $7^{\circ} 14^{\prime}$ North and Longitude $8^{\circ} 21^{\prime}$ East and lies within the Southern guinea savannah region of Nigeria. The area is warm with temperature range of 24.20 to $36.33^{\circ} \mathrm{C}$ and high temperature is experienced between late February and April. The rainfall is between 508 and $1016 \mathrm{~mm}$ (TAC, 2009).

\section{Management of Birds}

A total of 30healthy cocks, ten from each genotype (10 frizzle, 10 naked-neck and 10 normal feather cocks) were purchased from different farmers in Makurdi. The chickens were quarantined for a period of two weeks. During this period, the cocks were fed commercial poultry ration and water offered ad libitum.

\section{Biometry of male genitalia}

Five cocks of similar weights were selected from each of the three genotypes ( 5 frizzle, 5 naked-neck and 5 normal feather cocks) and slaughtered. The reproductive tracts were carefully removed with the aid of a razor blade. Various components of the reproductive tract namely, testis, epididymis and vas deferens were separated, trimmed free of fats and weighed using a sensitive weighing balance. The lengths of the various components were measured using a meter rule. The testes circumferences were determined with the aid of a thread and a meter rule. The testes volume was determined by displacement technique. The birds were eviscerated and the absolute weights of the lungs, liver, heart, spleen, and kidneys recorded. The relative weights of the organs were determined as follows:

Relative organ weight $=\frac{\text { organ weight } \times 100}{\text { Weight of birds }}$

\section{Statistical Analysis}

Data obtained were subjected to one way analysis of variance using GenStat (release 4:24) statistical package GenStat, 2005.Significant differences between treatment means were separated using Duncan's Multiple Range Test of the same software.

\section{RESULTS AND DISCUSSION}

The results of live weight and biometry of the male genitalia of Nigeria indigenous genotypes of domestic fowl in the Southern Guinea Savanna Region of 
Nigeria are presented in Table 1. The average mean left, right and paired testes were $5.27 \pm 0.34,4.98 \pm 2.10$ and $10.25 \pm 3.90 \mathrm{~g}$ respectively. The comparison of the biometric values of the testes in the different genotypes showed non significant differences $(p>0.05)$ in left, right and paired testes weights. The mean weight of the testes recorded in the present study is lower than the value of $12.17 \pm 4.75 \mathrm{~g}$ reported by Bath and Chaudhari (2002) in local cock in the Sahel region of Nigeria. However paired testes values in Normal feather and naked neck obtained in this study were comparable to the values of $11.7 \pm 1.14$ and $10.10 \pm 1.76$ for Normal feather and naked neck respectively reported by Oke and Ihemeson (2010). This observation disagreed with the findings of Oke and Ihemeson (2010) who observed that the testes of the frizzle feather cock had significant $(p<0.05)$ lower mean value than the normal feather and naked neck fowls. The size of the testis has been reported as a good

Table 1: Live weight and morphometric characteristics of reproductive organs of three genotypes

\begin{tabular}{lllll}
\hline Parameters & $\begin{array}{l}\text { Normal } \\
\text { feather }\end{array}$ & Naked neck & Frizzle & Average \\
Live weight $(\mathrm{kg})$ & $1.52 \pm 0.10$ & $1.7 \pm 0.76$ & $1.55 \pm 0.01$ & $1.59 \pm 0.60$ \\
Left Testis weight $(\mathrm{g})$ & $5.00 \pm 1.99$ & $5.61 \pm 2.39$ & $5.20 \pm 2.30$ & $5.27 \pm 0.34$ \\
Right testis weight $(\mathrm{g})$ & $4.13 \pm 1.50$ & $5.23 \pm 2.31$ & $5.59 \pm 2.35$ & $4.98 \pm 2.10$ \\
Paired testes weight $(\mathrm{g})$ & $9.13 \pm 3.2$ & $10.84 \pm 4.60$ & $10.79 \pm 4.60$ & $10.25 \pm 3.90$ \\
Left Epididymis weight $(\mathrm{g})$ & $0.15 \pm 0.07$ & $0.16 \pm 0.07$ & $0.15 \pm 0.04$ & $0.15 \pm 0.06$ \\
Right Epididymis weight $(\mathrm{g})$ & $0.14 \pm 0.03^{\mathrm{b}}$ & $0.17 \pm 0.60^{\mathrm{a}}$ & $0.17 \pm 0.05^{\mathrm{a}}$ & $0.16 \pm 0.05$ \\
Paired Epididymis weight $(\mathrm{g})$ & $0.30 \pm 0.11$ & $0.33 \pm 0.12$ & $0.32 \pm 0.04$ & $0.32 \pm 1.00$ \\
Left vas deferens weight $(\mathrm{g})$ & $0.39 \pm 0.13$ & $0.30 \pm 0.07$ & $0.35 \pm 0.07$ & $0.35 \pm 0.08$ \\
Right vas deferens weight $(\mathrm{g})$ & $0.28 \pm 0.11^{\mathrm{b}}$ & $0.36 \pm 0.11^{\mathrm{b}}$ & $0.55 \pm 0.06^{\mathrm{a}}$ & $0.40 \pm 0.09$ \\
Paired vas deferens weight $(\mathrm{g})$ & $0.67 \pm 0.24^{\mathrm{b}}$ & $0.64 \pm 0.15^{\mathrm{b}}$ & $0.90 \pm 0.12^{\mathrm{a}}$ & $0.74 \pm 0.17$ \\
Left testis length $(\mathrm{cm})$ & $3.83 \pm 1.13^{\mathrm{a}}$ & $2.83 \pm 0.20^{\mathrm{a}}$ & $1.93 \pm 0.38^{\mathrm{b}}$ & $2.86 \pm 0.21$ \\
Right testis length $(\mathrm{cm})$ & $3.73 \pm 0.84^{\mathrm{a}}$ & $2.70 \pm 0.06^{\mathrm{ab}}$ & $2.17 \pm 0.42^{\mathrm{b}}$ & $2.87 \pm 0.07$ \\
Right testis volume $\left(\mathrm{cm}{ }^{3}\right)$ & $4.33 \pm 1.76$ & $5.33 \pm 2.33$ & $4.33 \pm 2.67$ & $4.66 \pm 0.21$ \\
Left testis volume $\left.(\mathrm{cm})^{3}\right)$ & $5.00 \pm 2.08$ & $5.33 \pm 2.33$ & $6.33 \pm 2.67$ & $5.55 \pm 0.22$ \\
Left testis circumference $(\mathrm{cm})$ & $5.03 \pm 0.77$ & $5.30 \pm 1.17$ & $5.47 \pm 1.20$ & $5.20 \pm 1.10$ \\
Right testis circumference $(\mathrm{cm})$ & $4.53 \pm 0.48$ & $5.23 \pm 1.26$ & $5.13 \pm 1.28$ & $4.96 \pm 1.30$ \\
Left Epididymis Length $(\mathrm{cm})$ & $1.27 \pm 0.19$ & $1.70 \pm 0.20$ & $1.50 \pm 0.06$ & $1.49 \pm 0.30$ \\
Right Epididymis Length $(\mathrm{cm})$ & $1.40 \pm 0.0$ & $1.93 \pm 0.23$ & $1.90 \pm 0.05$ & $1.74 \pm 0.10$ \\
Left vas deferens length $(\mathrm{cm})$ & $11.03 \pm 0.17$ & $9.97 \pm 0.43$ & $10.40 \pm 0.92$ & $10.67 \pm 0.60$ \\
Right vas deferens length $(\mathrm{cm})$ & $10.37 \pm 0.47$ & $11.73 \pm 0.43$ & $10.90 \pm 0.85$ & $11.00 \pm 0.70$ \\
\hline
\end{tabular}

${ }^{\mathrm{a} b}$ means in the same row with different superscripts are significantly $(\mathrm{p}<0.05)$ different.

Indicator of present and future sperm production as well as breeding quality of the male (Ezekwe, 1998; Perry and Petterson, 2001; Togun and Egbunike, 2006).

The average mean left, right and paired epididymis weights were $0.15 \pm 0.06,0.16 \pm 0.05$ and $0.32 \pm 0.10 \mathrm{~g}$ respectively. The comparison of the biometric values of the epididymis in the different genotypes showed non significant differences $(p<0.05)$ in left and paired epididymis weights. But significant differences $(p<0.05)$ were observed in the right epididymis weights. The mean weight values of the right epididymis of a normal feather birds $(0.14 \pm 0.03)$ was significantly $(p<0.05)$ lower than the naked neck value $(0.17 \pm 0.60 \mathrm{~g})$ and frizzle feather value $(0.17 \pm 0.05 \mathrm{~g})$. This difference suggests genetic influence on the right epididymis of the fowl genotypes. The result contrast the findings of Oke and Ihemeson (2010) who observed no significant $(p>0.05)$ variation in the weights of the right epididymis of the three genotypes.

The average mean left, right and paired vas deferens weights were $0.35 \pm 0.08,0.40 \pm 0.09$ and $0.74 \pm 0.17 \mathrm{~g}$ respectively. The right and paired vas deferens weights of the frizzle cock showed significantly $(p<0.05)$ lower values from normal and naked neck cocks respectively. The mean weight of the right vas deferens of fizzled feather bird $(0.55 \pm 0.6 \mathrm{~g})$ was significantly $(\mathrm{p}<0.05)$ different from naked neck value $(0.36 \pm 0.11 \mathrm{~g})$ and normal feather birds $(0.28 \pm 0.11 \mathrm{~g})$ respectively. No significant $(P>0.05)$ difference was recorded in the mean value of the left vas deferens weights of three fowl genotypes. This result agrees with the report of Oke and Ihemeson (2010) who observed no significant differences $(p>0.05)$ in the weights of the left vas deferens of the three genotypes. The left vas deferens values obtained in this study were lower than the values of $1.10 \pm 0.15,1.14 \pm 0.35$ and $0.89 \pm 0.53$ for Normal feather, naked neck and frizzle feather respectively as reported by Oke and Ihemeson (2010). Similarly the right vas deferens values obtained in this study were lower than the values of $1.05 \pm 0.15$, $0.51 \pm 0.85$ and $0.77 \pm 0.33$ for Normal feather, naked neck and frizzle feather respectivelyas reported by 
Oke and Ihemeson (2010). This may be attributed to age and weights of the birds.

The average mean left and right testes lengths were $2.86 \pm 0.2$ and $2.87 \pm 0.07 \mathrm{~cm}$ respectively. The testis length recorded in this study was lower than the value of $3.42 \pm 0.50 \mathrm{~cm}$ reported by Bath and Chaudhari (2002) in local cock in the Sahel region of Nigeria. The length of the testes from the three fowl genotypes were significantly $(p<0.05)$ different. The values of right and left testes length were lower in frizzle feather cocks $(1.93 \pm 0.38$ and $2.17 \pm 0.42)$ than other genotypes. According to Ezekwe (1998) and Perry and Petterson (2001), testes size, length and width are good indicators of present and future sperm production. Ugwu (2009) asserted that a good measurement of testes length and width would be a reliable predictor of the sperm producing capacity of bucks.

The average mean left and right testes volumes were $4.66 \pm 0.21$ and $5.55 \pm 0.22 \mathrm{~cm}^{3}$ respectively. The testis volume recorded in this study was lower than the value of $11.74 \pm 4.53 \mathrm{~cm}^{3}$ reported by Bath and Chaudhari (2002) in local cock in the Sahel region of Nigeria. The volume of the left testis of $5.00 \pm 2.08 \mathrm{ml}$, $5.33 \pm 2.33 \mathrm{ml}$, and $6.33 \pm 2.67 \mathrm{ml}$ for normal feather bird, naked neck and frizzle feather respectively were not significantly $(p>0.05)$ different.

The average mean left and right epididymis lengths were $1.49 \pm 0.30$ and $1.74 \pm 0.10 \mathrm{~cm}$ respectively. The epididymis length recorded in this study was lower than the value of $1.91 \pm 0.39 \mathrm{~cm}$ reported by Bath and Chaudhari (2002) in local cock in the Sahel region of Nigeria. The differences may be due to the body weight and environment. The length of the right testis of a naked neck value $5.33 \pm 2.33 \mathrm{~cm}$ was not significantly $(p>0.05)$ different from normal feather, $(4.33 \pm 1.67)$. Significant $(p<0.05)$ difference however was observed between normal feather cock and the fizzle feather cock in their mean values of testicular lengths (both right and left testes). The mean left and right vas deferens lengths were $10.67 \pm 0.6$ and $11.00 \pm 0.70 \mathrm{~cm}$ respectively. The vas deferens length values obtained in this study were comparable to the value of $11.59 \pm 1.34 \mathrm{~cm}$ reported by Bath and Chaudhari (2002) in local cock in the Sahel region of Nigeria.

Positive significant relationship were observed between live weight and testes weight $(r=0.65 ; p<0.05)$ as well as epididymal weight $(r=0.85 ; p<0.05)$ inTable 2. The good and positive correlations between live weight and testes weight indicates the possibility of predicting testes weight from live weight Since testes weight is known to be very highly correlated with sperm production and testicular sperm reserves (Ahemenet al. 2013). Togunet al. (2006) also reported live weight to be significantly correlated with testes weight. Males with larger testes will tend to produce more sperm.

\section{Table 2: Correlation matrix of Live weight and biometry of the male genitalia of Indigenous fowl}

\begin{tabular}{lllllllll}
$\mathrm{Lw}$ & $\mathrm{Tw}$ & $\mathrm{Tc}$ & $\mathrm{Tl}$ & $\mathrm{TV}$ & $\mathrm{Ew}$ & $\mathrm{El}$ & $\mathrm{Dw}$ & $\mathrm{DI}$ \\
\hline
\end{tabular}

Lw 1.00

Tw $0.65^{\star} \quad 1.00$

Tc $\quad 0.28 \quad 0.91^{\star *} \quad 1.00$

$\mathrm{TI} \quad-0.18-0.87^{* *}-0.99^{\star *} \quad 1.00$

Tv $\quad 0.99^{\star *} \quad 0.52^{*} \quad 0.13 \quad-0.03 \quad 1.00$

Ew $0.85^{\star *} \quad 0.95^{\star *} \quad 0.95^{\star *} \quad-0.68^{*} \quad 0.76^{\star *} \quad 1.00$

El $\quad 0.92^{\star *} \quad 0.90^{\star *} \quad 0.64^{\star} \quad 0.57^{\star} \quad 0.85^{\star *} \quad 0.99^{\star *} \quad 1.00$

Dw $-0.46^{*} \quad 0.40 \quad 0.73^{* *} \quad 0.79^{* *} \quad 0.62^{*} \quad 0.08 \quad-0.07 \quad 1.00$

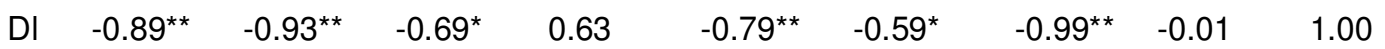

** Correlation is significant at $1 \%(\mathrm{P}<0.01),{ }^{*}$ Correlation is significant at $5 \%(\mathrm{P}<0.05) \mathrm{LW}=$ live weight, $\mathrm{Tw}=$ Testis weight, $\mathrm{Tc}=$ Testis circumference, $\mathrm{Tl}=$ Testis length, $\mathrm{TV}=$ testis volume, $\mathrm{Ew}=$ epididymal weight, $\mathrm{El}=$ Epididymal length, Ductud weight. Ductus length

Table 3 showed a summary of some derivations from morphometric of the reproductive organs of the three fowl genotypes. The paired testes values were not significantly $(p>0.05)$ different. The values obtained ranged from $0.58 \pm 0.19-0.63 \pm 0.29$. This agrees with the report of Bath and Chaurdhari, (2002) who stated that the testes is made up of $0.64 \pm 0.22$ of the live body weight of Local Cocks in the Sahel Region of 
Nigeria.Burke, 1977 however, stated that in a sexually active cock, the testis made up $1 \%$ of body weight. The paired vas deferens weights were similar $(p>0.05)$ to each other. This observations agreewith the findings of
Ibrahim et al. (2012)that all the derivations from the morphometric characteristics measured were unaffected by breed in the three breeds of sheep (Uda, Balami and Yankassa breeds) studied.

Table 3: Some derivations from the morphometric characteristics of the reproductive organs of the three fowl genotypes.

\begin{tabular}{lllll}
\hline Parameters & Normal feather & Naked neck & Frizzled feather & Los \\
\hline Paired testis (\%) Weight & $0.58 \pm 0.19$ & $0.62 \pm 0.26$ & $0.63 \pm 0.29$ & $\mathrm{~ns}$ \\
Paired Epididymal (\%) Weight & $0.02 \pm 0.01$ & $0.02 \pm 0.01$ & $0.02 \pm 0.01$ & $\mathrm{~ns}$ \\
Paired vas deferens (\%) Weight & $0.06 \pm 0.01$ & $0.04 \pm 0.01$ & $0.04 \pm 0.01$ & $\mathrm{~ns}$ \\
\hline
\end{tabular}

Los $=$ Level Significance, $n s=$ Not significance at $5 \%$

The absolute and relative values (\%) of the visceral organ weight of the three fowl genotypes (Table 4) showed that the absolute mean values of the spleen of a normal feather $(4.57 \pm 0.38)$, Naked neck $(4.01 \pm 1.22)$ and frizzle feather $(2.92 \pm 0.45 \mathrm{~g})$ were significantly $(p<0.05)$ influenced by fowl genotypes. The relative values of the spleen, lungs and liver were significantly $(p<0.05)$ different from each other within the three genotypes. The difference in mean relative weights recorded in some visceral organ was attributed to genetic factor in the birds. The relative values of the heart, lungs and liver were similar to the values of 0.46-0.55, 0.60-0.66 and 2.12-2.52 for heart, lungs and liver respectively reported by Ashom et al. (2014) in broiler chickens. The observed spleen mean value was however higher than the range of $0.11-1.70$ reported by Ashom et al. (2014).

Table 4: Absolute and relative values (\%) of visceral organ weight of three fowl genotypes

\begin{tabular}{llll}
\hline Parameters & Normal feather & Naked neck & Frizzle Feather \\
Spleen $(\mathrm{g})$ & $4.57 \pm 0.38^{\mathrm{a}}$ & $4.01 \pm 1.22^{\mathrm{a}}$ & $2.92 \pm 0.45^{\mathrm{b}}$ \\
Heart $(\mathrm{g})$ & $6.38 \pm 0.37$ & $7.24 \pm 0.67$ & $6.34 \pm 0.15$ \\
Lungs & $9.22 \pm 0.81$ & $8.61 \pm 0.16$ & $9.21 \pm 0.51$ \\
Kidney (g) & $5.34 \pm 0.62$ & $5.86 \pm 0.30$ & $6.26 \pm 1.43$ \\
Relative values (\% live weight) & & & \\
Spleen & $0.31 \pm 0.04^{\mathrm{a}}$ & $0.23 \pm 0.08^{\mathrm{ab}}$ & $0.19 \pm 0.02^{\mathrm{b}}$ \\
Heart & $0.42 \pm 0.02$ & $0.41 \pm 0.03$ & $0.41 \pm 0.02$ \\
Lungs & $0.62 \pm 0.39^{\mathrm{a}}$ & $0.49 \pm 0.03^{\mathrm{ab}}$ & $0.59 \pm 0.04^{\mathrm{b}}$ \\
Liver & $2.18 \pm 0.18^{\mathrm{a}}$ & $1.74 \pm 0.016^{\mathrm{b}}$ & $1.98 \pm 0.28^{\mathrm{ab}}$ \\
Kidney & $0.35 \pm 0.02$ & $0.33 \pm 0.10$ & $0.41 \pm 0.11$ \\
\hline ab & & &
\end{tabular}

${ }^{\mathrm{ab}}$ means in the same row with different superscripts are significantly $(p<0.05)$.

\section{CONCLUSION}

The result of the study provides baseline data on biometry of the male genitalia of indigenous genotypes of domestic fowl in the southern guinea savanna region of Nigeria. The result will also help in research on anatomy and physiology of the domestic fowl in the study area and selection for genetic improvement of these birds. It is recommended that further studies on other aspects of reproduction like endocrinology and 
spermiogram be conducted to establish baseline data that may enhance genetic improvement of these birds in the study area.

\section{REFERENCES}

Ahemen, T, Abu, AH and Orakaanya, TT (2013). Sperm quality, testicular morphometry of rabbits fed dietary levels of water spinach (Ipomoea aquatica) leaf meal. Agric. Biol. J. N. Am., 2013, 4(3): 352-357 http://www.scihub.org/ABJNA

Ashom SA, Tuleun, CD and Carew SN (2014). Growth, carcass and internal organ characteristics of finisher chickens fed processed Roselle (Hibiscus sabdariffa L) seed meal diets. Journal of biology, agriculture and Healthcare 424 pp141- 145

Bath, GS and Chaurdhari, SUR (2002).Sperm Reserve and its Relationship to Parameters of the Testis, Epididymis and Vas Deferns of Local Cocks in the Sahel Region of Nigeria. International Journal of Agricultural and Biology.1560-8530/2002/04-4562-564.

Burke, WH (1977). Avian reproduction.In: Swenson, M.S. (ed), Duke'sPhysiology of Domestic Animals, 9th Ed., p. 825. Cornell UniversityPress Ltd., USA

Egbunike, GN, Holtz, W and Sidt, D (1976). Reproductive capacity of German Landrace boars, 11: Sperm production rates as determined by quantitative testicular histology and from gonadal sperm reserves. Zuchthygeine, 11:35-47.

Ezekwe, AG (1998). Gonadal and extragonadal sperm reserve and testicular histometry of post pubertal Muturu bulls. Nig. J. Anim. Prod., 25: 106-110.

GenStat (2005).GenStat user's Guide (Release 4.24). Lawes Agricultural Trust, Rothamsted Experimental station, UK.

Hafez, B and Hafez, ESE (2000). Reproduction in Farm Animals, 7th Ed., : 5-7. Lea and Fabiger, Philadelphia

Horst, P (1988). Mature fowl as reservoir for genomers and major genes with direct and indirect effect on production adaptability. In: proceedings of $18^{\text {th }}$ World Poutry Congress, Mgoya, Japan, 4-6 September, pp 105.
Ibrahim, AA, Aliyu, J, Ashiru, M and Jamilu.M (2012). Biometric Study of the Reproduction Organs of Three Breeds of Sheep in Nigeria. Int. J. Morpho., 30(4): 1597-1603, 2012.

Lake PE., Rule, O and Naddington, N (1985). Some effects of the composition of inseminated semen and site of its deposition and fertility in Gallus domesticus. Animal Reproduction Science 9:273-284.

Oke, UK and Ihemeson, C (2010).Effect of genotype on the morphometric differentiation of the reproductive organs and sperm reserves in Nigerian local chicken. Livestock Research for Rural Development 22(23) 2010. www.irrd.org/irrd22/3/oke22053.htm-Cached.

Oke,UK,Herbert, U,Ebuzoeme, C and Nwachukwu, EN (2007) Effect of genotype on haematology of Nigerian local chicken, IN: proceedings of the $32^{\text {nd }}$ Annual Conference of the Nigerian Society of Animal Production NSAP Calabar, Nigeria. Pp 123-1256.

Perry G,and Petterson D. (2001). Determining reproductive fertility in herd bulls. University of Missouri Agriculture publication 2011:1-8.

Rim,(1992). Recourses Inventory and Management in Nigeria.National Livestock Survey; Federal Department of livestock and pest control services Abuja, Nigeria.

Siddiqui, HUR, Ahmad, A and Khan, MZ (2005). Biometrical studies of testes of ram. J. Agric. Social Sci., 1: 78-79.

TAC (2009).Makurdi Weather Elements Records, MakurdiMetereological Station. Nigeria Air Force, Tactical Air Command, Makurdi, Nigeria.

Togun, VA andEgbunike, GN(2006). Seasonal variations in the sperm production characteristics of Zebu (white Fulani) cattle genitalia in the humid tropical environment. Middle-East J. Sci. Res., 1: 87-95.

Ugwu, SOC (2009).Relationship between Scrotal circumferences, insitu Testicular Measurement and Sperm Reserves in the West African Dwarf Bucks.Afr. J. Biotechnol., 8(7):1354-7,. 